\title{
Synergistic effect of the herbal mixture C5E on gemcitabine treatment in PANC-1 cells
}

\author{
PYO JUNE PAK ${ }^{1 *}$, DONG GUN LEE ${ }^{1 *}$, JI HYUN SUNG ${ }^{2}$, SEUNG HYUN JUNG ${ }^{3}$, \\ TAE-YOUNG HAN ${ }^{4}$, SUNG HYO PARK ${ }^{1}$ and NAMHYUN CHUNG ${ }^{1}$
}

\author{
${ }^{1}$ Department of Biosystems and Biotechnology, College of Life Sciences and Biotechnology, Korea University, Seoul 02841; \\ ${ }^{2}$ Flow Cytometry Core Facility, Biomedical Research Institute, Seoul National University Hospital, Seoul 03082; \\ ${ }^{3}$ School of Oriental Medicine, Dongguk University, Ilsan 10326; ${ }^{4}$ BanryongInsu Herb Clinic, Seoul 06099, Republic of Korea
}

Received April 1, 2020; Accepted September 28, 2020

DOI: $10.3892 / \mathrm{mmr} .2021 .11954$

\begin{abstract}
The present study aimed to determine the anticancer effect of the herbal mixture extract C5E in the pancreatic cancer cell line, PANC-1, in the absence or presence of gemcitabine treatment, a chemotherapeutic drug used for the treatment of pancreatic cancer. The anticancer effects of $\mathrm{C} 5 \mathrm{E}$, gemcitabine and C5E plus gemcitabine in PANC-1 cells following $72 \mathrm{~h}$ of treatment were investigated. The effect of each treatment on cell cycle arrest, apoptosis and the proportion of side population (SP) cells was determined using flow cytometric analysis following propidium iodide (PI), Annexin V-FITC/PI double staining and Hoechst 33342 staining, respectively. SP cells share similar characteristics to cancer stem-like cells, and a reduction in the SP is considered to be indicative of an anticancer effect. The percentage of SP cells and the cell viability of general PANC-1 cells were significantly decreased in response to all treatments. The percentage of SP cells was reduced from $8.2 \%$ (control) to $3.9,7.2$ and $5.1 \%$ following the treatment with C5E, gemcitabine and the co-treatment, respectively. All three treatments were discovered to inhibit cell viability by arresting the cell cycle at the $\mathrm{S}$ phase and promoted cell death by inducing early apoptosis, with the levels of apoptosis being increased from 1.9\% (control) to 7.3, 2.5 and $12.0 \%$ following the treatment with $\mathrm{C} 5 \mathrm{E}$, gemcitabine and the co-treatment, respectively. The mRNA expression levels of sonic hedgehog, which is implicated in the development of certain types of cancer, were downregulated to a greater extent following the co-treatment with $\mathrm{C} 5 \mathrm{E}$ and gemcitabine compared with
\end{abstract}

Correspondence to: Professor Namhyun Chung, Department of Biosystems and Biotechnology, College of Life Sciences and Biotechnology, Korea University, 145 Anam-ro, Seongbuk, Seoul 02841, Republic of Korea

E-mail: nchung@korea.ac.kr

${ }^{*}$ Contributed equally

Key words: cancer stem-like cells, gemcitabine, herbal mixture extract, PANC-1 cells, side population, traditional Chinese medicine the treatment with either C5E or gemcitabine alone. As the co-treatment with gemcitabine and C5E was more effective than each individual treatment, the present study suggested that the combined treatment may exhibit synergistic effects in PANC-1 cells.

\section{Introduction}

Pancreatic cancer is a fatal disease, representing the fourth leading cause of cancer-related deaths worldwide. Only a few patients demonstrate a sustained response to chemotherapy or radiation therapy due to drug resistance or toxicity, and patient prognosis is extremely poor, demonstrating a 5-year survival rate of only $3 \%$ (1-3). The majority of patients with pancreatic cancer are diagnosed with an advanced-stage disease because of its poor prognosis; this excludes the possibility of surgery. A chemotherapy regimen with gemcitabine is the most common treatment prescribed for advanced pancreatic cancer (2). Although some progress has been made with respect to novel targeted therapies and combination therapies for patients, the overall survival rate has not been significantly improved (3).

Cancer stem-like cells (CSCs) have been investigated and used for the development of novel cancer therapies by serving as biomarkers in lung, liver and pancreatic cancer (4-6). CSCs exhibit properties that are similar to those of normal stem cells, such as a long lifespan with relative quiescence, resistance to drugs and toxins through the expression of several ATP-binding cassette (ABC) transporters, an active DNA-repair capacity and resistance to apoptosis (7). Previous studies have indicated that CSCs may serve an important role in cancer cell migration and the development of drug resistance in cancer cells $(8,9)$. The presence of CSCs can be determined by analyzing the side population (SP), a subpopulation of cells that express $\mathrm{ABC}$ superfamily $\mathrm{G}$ member 2, and thus, are multidrug-resistant (10). Using dual wavelength flow cytometry, SP cells can be identified by their ability to efflux Hoechst 33342 dye $(11,12)$.

Several studies have reported that extracts of herbal mixtures are excellent agents for the treatment of various types of disease, including cardiovascular and Alzheimer's disease and dermatitis (13-15). For example, extracts of herbal mixtures have been shown to exhibit anticancer, anti-inflammatory, 
antibacterial and antioxidative effects (16-19). In particular, the observed anticancer effects of herbal mixture extracts have included their ability to boost the efficacy of standard chemotherapies and reduce side effects during chemotherapy (16). In the current study, a novel cocktail of 10 types of traditional Chinese medicine herbs was made, based on the advice of a medical doctor who had experience in treating cancer. The anticancer efficacy of the combined treatment with the herbal mixture extract, C5E, and gemcitabine was investigated. The C5E mixture consisted of several herbal extracts (described in the Materials and methods section), which are widely used to treat several types of disease, including cancer (20-23). One of the ingredients, Panax ginseng (Korean ginseng) is a well-known herbal medicine, which has been reported to reduce the proliferative ability of prostate and lung cancer cells $(20,21)$. Another ingredient, Inonotus obliquus, is a type of mushroom commonly known as chaga, which was previously identified to have both antioxidative and anticancer effects $(22,23)$.

\section{Materials and methods}

Cell culture. The human pancreatic carcinoma cell line, PANC-1, was obtained from the Korean Cell Line Bank; Korean Cell Line Research Foundation (cat. no. 21469). PANC-1 cells were cultured in DMEM (Welgene, Inc.) supplemented with $100 \mathrm{U} / \mathrm{ml}$ penicillin, $100 \mu \mathrm{g} / \mathrm{ml}$ streptomycin and $10 \%$ heat-inactivated FBS (Welgene, Inc.). The culture was maintained at $37^{\circ} \mathrm{C}$ in a humidified atmosphere of $5 \% \mathrm{CO}_{2}$.

Preparation of the herbal mixture extract, C5E. C5E consisted of ten traditional Chinese medicinal herbs. The proportions, manufacturing process and analyses of the major components were previously reported (8). C5E was prepared using $16.6 \%$ Panax ginseng (w/w; supplied from Kyung-dong market, Seoul, Republic of Korea), $16.6 \%$ Inonotus obliquus, $11.1 \%$ Pinellia ternata, $5.6 \%$ rhizome of Sparganium stoloniferum Buchanan-Hamilton, 5.6\% Alpinia galanga, $5.6 \%$ Cinnamomum cassia, 5.6\% Astragalus membranaceus, $11.1 \%$ Psoralea corylifolia L., $11.1 \%$ Tetradium ruticarpum and $11.1 \%$ Melia azedarach $L$. The medicinal herbs were obtained from the Oriental Medical Hospital, Dongguk University (Ilsan, Republic of Korea). C5E was prepared as follows: The dried and pulverized herbs were mixed and a $1 \mathrm{~kg}$ batch was soaked and slowly stirred overnight at $25^{\circ} \mathrm{C}$ with 31 ethanol $(40 \%)$. The ethanol extract was concentrated using a rotary evaporator to remove solvent, lyophilized at $-80^{\circ} \mathrm{C}$ using a freeze-dryer (FDU-2110; Eyela) and reconstituted in Milli-Q water (18.2 M $\Omega$; EMD Millipore) for in vitro studies.

Treatment with gemcitabine and/or C5E. PANC-1 cells were seeded at a density of $5 \times 10^{5}$ cells $/ \mathrm{ml}$ and subjected to three different treatments and control: i) $10 \mathrm{nM}$ gemcitabine (Sigma-Aldrich; Merck KGaA); ii) $30 \mu \mathrm{g} / \mathrm{ml} \mathrm{C5E}$; and iii) pretreatment with $15 \mu \mathrm{g} / \mathrm{ml} \mathrm{C} 5 \mathrm{E}$ for $2 \mathrm{~h}$ before treatment with $5 \mathrm{nM}$ gemcitabine; iv) untreated control. After $72 \mathrm{~h}$ of treatment at $37^{\circ} \mathrm{C}$, the cells were harvested at the logarithmic growth stage by treatment with $0.05 \%$ trypsin-EDTA and centrifugation $\left(220 \mathrm{x} \mathrm{g} ; 3 \mathrm{~min} ; 25^{\circ} \mathrm{C}\right)$. Cells were resuspended in an equal volume of DMEM (Welgene, Inc.), then a $10 \mu \mathrm{l}$ sample was stained for $10 \mathrm{sec}$ with $10 \mu \mathrm{l} 0.4 \%$ trypan blue dye at $25^{\circ} \mathrm{C}$. Viability was determined by cell counting using hemocytometer and the half maximal inhibitory concentration $\left(\mathrm{IC}_{50}\right)$ values were calculated as previously described (24).

Analysis of cell cycle distribution. Cell cycle progression was analyzed by flow cytometry. Following $72 \mathrm{~h}$ incubation at $37^{\circ} \mathrm{C}$, PANC-1 cells were harvested using trypsin-EDTA treatment as described above and washed twice with PBS. When cells were harvested for SP analysis, the population was divided in half: One half was used for SP analysis, and the other half was used to examine cell cycle arrest. The cells were fixed in ice-cold $70 \%$ ethanol at $-20^{\circ} \mathrm{C}$ for $24 \mathrm{~h}$. Prior to flow cytometric analysis, the ethanol was removed by centrifugation $(250 \mathrm{x} \mathrm{g}$, $5 \mathrm{~min}, 25^{\circ} \mathrm{C}$ ) and the cells were washed and resuspended in $5 \mathrm{ml}$ PBS. $100 \mu \mathrm{l}$ propidium iodide (PI) staining solution containing $50 \mu \mathrm{g} / \mathrm{ml}$ PI (Sigma-Aldrich; Merck KGaA) diluted in $1 \mathrm{X}$ PBS, $1 \mathrm{mg} / \mathrm{ml}$ RNase (Sigma-Aldrich; Merck KGaA) diluted in $1 \mathrm{X}$ PBS and $0.1 \%$ Triton X-100 was added to a FACS tube and incubated in the dark at room temperature for $30 \mathrm{~min}$. Cell cycle analysis was performed using a FACSCalibur flow cytometer (BD Biosciences) at an excitation wavelength of $488 \mathrm{~nm}$ and an emission wavelength of $610 \mathrm{~nm}$ by measuring the amount of PI-labeled DNA in the cells. Data were analyzed using ModFit LT ${ }^{\mathrm{TM}}$ version 3.0 software (Verity Software House, Inc.).

Flow cytometric analysis of early and late apoptosis. Flow cytometric analysis was performed using an FITC Annexin V Apoptosis Detection kit I (BD Biosciences). PANC-1 cells were harvested via trypsin-EDTA treatment as described above, washed twice with PBS and centrifuged $\left(250 \mathrm{x} \mathrm{g}, 5 \mathrm{~min}, 25^{\circ} \mathrm{C}\right)$. The pellets were resuspended in $100 \mu \mathrm{l}$ Annexin $\mathrm{V}$ binding buffer, and then incubated with $5 \mu \mathrm{l}$ Annexin V-FITC and $5 \mu \mathrm{l}$ PI for $15 \mathrm{~min}$ at room temperature in the dark. For the analysis, $300 \mu \mathrm{l}$ binding buffer was added to each mixture and analyzed using a FACSCalibur flow cytometer. The fluorescence intensity of Annexin V-FITC and PI was analyzed at an excitation/emission wavelength of 488/530 nm and 488/617 $\mathrm{nm}$, respectively. The data were analyzed using BD CellQuest Pro software version 5.2.1 (Becton Dickinson, Inc.) and apoptotic rate was calculated by the percentage of each of early and late apoptotic cells.

Analysis of SP cells. PANC-1 cells were harvested via treatment with trypsin-EDTA as described above and labeled with Hoechst 33342 dye (Sigma-Aldrich; Merck KGaA), using the methods described by Goodell et al (11). Briefly, the cells were resuspended at a density of $1 \times 10^{6}$ cells $/ \mathrm{ml}$ in pre-warmed DMEM (phenol red-free) containing 2\% FBS and $10 \mathrm{mM}$ HEPES buffer. Hoechst 33342 was added at a final concentration of $5 \mu \mathrm{g} / \mathrm{ml}$ in the presence or absence of $50 \mu \mathrm{M}$ verapamil (Sigma-Aldrich; Merck KGaA) which inhibits ABC transporter to prevent generation of SP cells, and the cells were incubated at $37^{\circ} \mathrm{C}$ for 90 min with intermittent mixing. Following the incubation, the cells were centrifuged $(250 \mathrm{x} \mathrm{g}$; $5 \mathrm{~min} ; 25^{\circ} \mathrm{C}$ ) and resuspended in ice-cold HBSS (Welgene, Inc.) containing 2\% FBS and $10 \mathrm{mM}$ HEPES buffer. The cells were then analyzed using a FACSAria ${ }^{\mathrm{TM}}$ flow cytometer (BD Biosciences). Hoechst 33342 was excited at $357 \mathrm{~nm}$, and its 

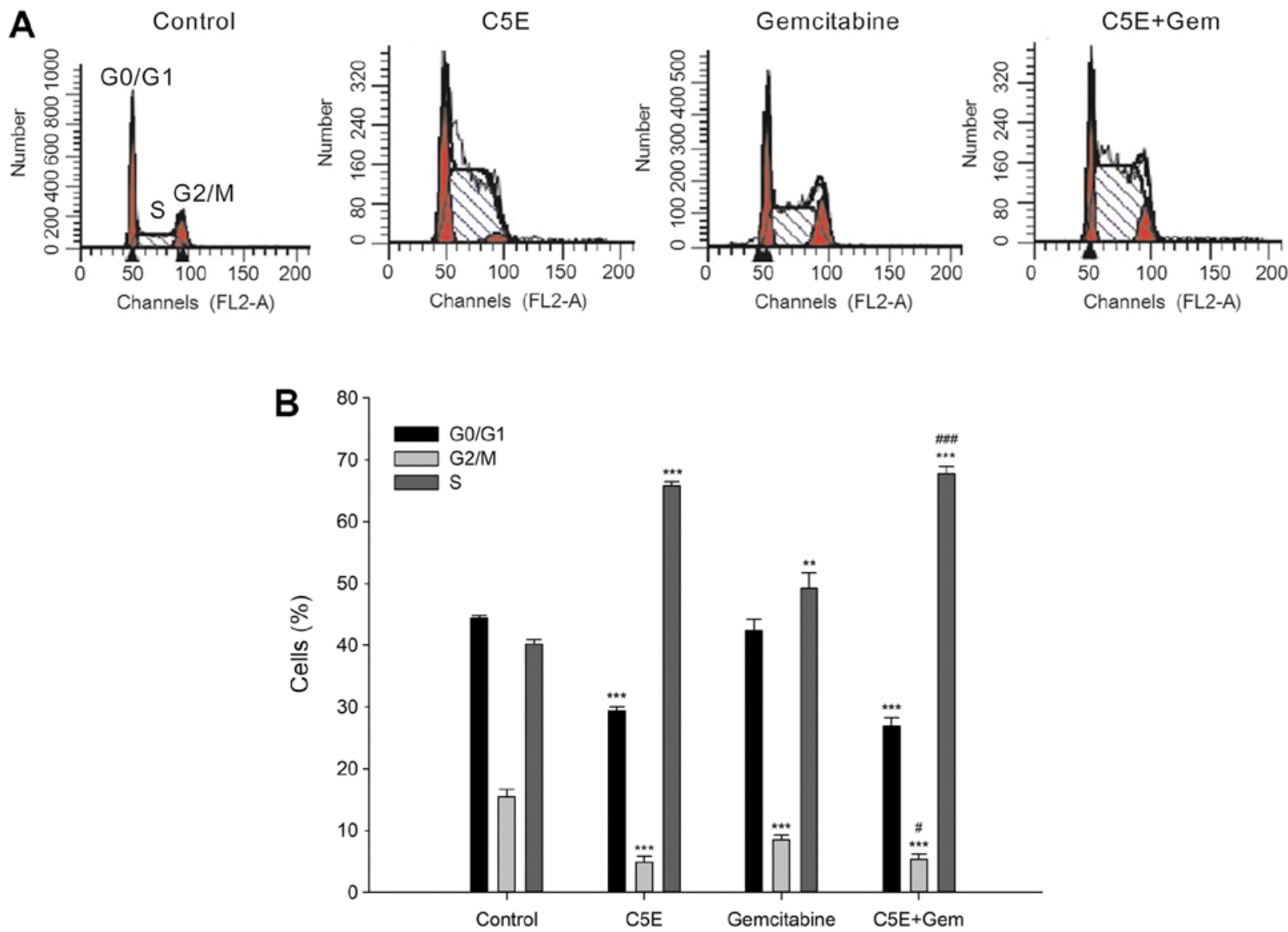

Figure 1. Induction of S phase cell cycle arrest following the treatment with C5E and/or gemcitabine. (A) Cell cycle analysis was performed using ModFit software following propidium iodide staining in the different treatment groups and flow cytometry. (B) Percentage of cells at each stage of the cell cycle in the different treatment groups. ${ }^{* *} \mathrm{P}<0.01,{ }^{* * * *} \mathrm{P}<0.001$ vs. the respective phase of the control group; ${ }^{\#} \mathrm{P}<0.05,{ }^{\# \# \#} \mathrm{P}<0.001$ vs. respective phase of gemcitabine.

fluorescence was analyzed using a dual-wavelength (blue, 402-446 nm; red, 650-670 nm). The data were analyzed using BD CellQuest Pro software (version 5.2.1; Becton Dickinson, Inc.).

Reverse transcription-quantitative PCR (RT-qPCR). Total RNA was extracted from cells using the RNeasy Mini kit (Qiagen, Inc.), according to the manufacturer's instructions, followed by processing with the QIAshredder homogenizer (Qiagen, Inc.). The RNase-free DNase set (Qiagen, Inc.) was used for further DNA removal. Oligo $(\mathrm{dT})_{14}$ single-stranded cDNA was synthesized from the RNA using AMV Reverse Transcriptase (Promega Corporation). The following conditions were used for cDNA synthesis: Initial incubation at $65^{\circ} \mathrm{C}$ for $5 \mathrm{~min}$; followed by $42^{\circ} \mathrm{C}$ incubation for $60 \mathrm{~min}$ and termination at $70^{\circ} \mathrm{C}$ for 5 min. qPCR was subsequently performed on a CFX Connect Real-Time PCR Detection system (Bio-Rad Laboratories, Inc.) using a TaqMan PreAmp Master Mix kit (Applied Biosystems; Thermo Fisher Scientific, Inc.). Commercially available primers were obtained for Sonic hedgehog (SHH) (cat. no. Hs00179843_m1; Applied Biosystems; Thermo Fisher Scientific, Inc.) and GAPDH (cat. no. Hs02786624_g1; Applied Biosystems; Thermo Fisher Scientific, Inc.). The following thermocycling conditions were used for qPCR: Initial denaturation for $10 \mathrm{~min}$ at $95^{\circ} \mathrm{C}$; followed by 45 cycles of denaturation for $15 \mathrm{sec}$ at $95^{\circ} \mathrm{C}$ and annealing/elongation at $60^{\circ} \mathrm{C}$ for $60 \mathrm{sec}$. The housekeeping gene, GAPDH, was used as an internal control. The expression levels were measured using the $2^{-\Delta \Delta \mathrm{Cq}}$ method (25). Data are expressed as the fold change relative to the expression levels in the control group.

Statistical analysis. Statistical analyses were performed using SPSS version 25.0 software (IBM Corp.). Data are expressed as the mean \pm SD of $\geq 3$ independent experiments. Significant differences were analyzed using a one-way ANOVA followed by a Tukey's test for multiple comparisons. $\mathrm{P}<0.05$ was considered to indicate a statistically significant difference.

\section{Results}

Inhibitory effects of C5E and/or gemcitabine. The viability of PANC-1 cells was evaluated using the trypan blue exclusion assay $72 \mathrm{~h}$ after $\mathrm{C} 5 \mathrm{E}$ treatment. The results revealed that C5E treatment inhibited cell viability in a dose-dependent manner (Fig. S1A). The $\mathrm{IC}_{50}$ of $\mathrm{C} 5 \mathrm{E}$ was calculated to be $30 \mu \mathrm{g} / \mathrm{ml}$ for PANC-1 cells. Gemcitabine also inhibited the cell viability of PANC-1 cells in a dose-dependent manner; the $\mathrm{IC}_{50}$ value of gemcitabine was calculated to be $10 \mathrm{nM}$ (Fig. S1B). Additionally, following the co-treatment with C5E and gemcitabine, the cell viability was also inhibited in a dose-dependent manner. The $\mathrm{IC}_{50}$ value of co-treatment with 

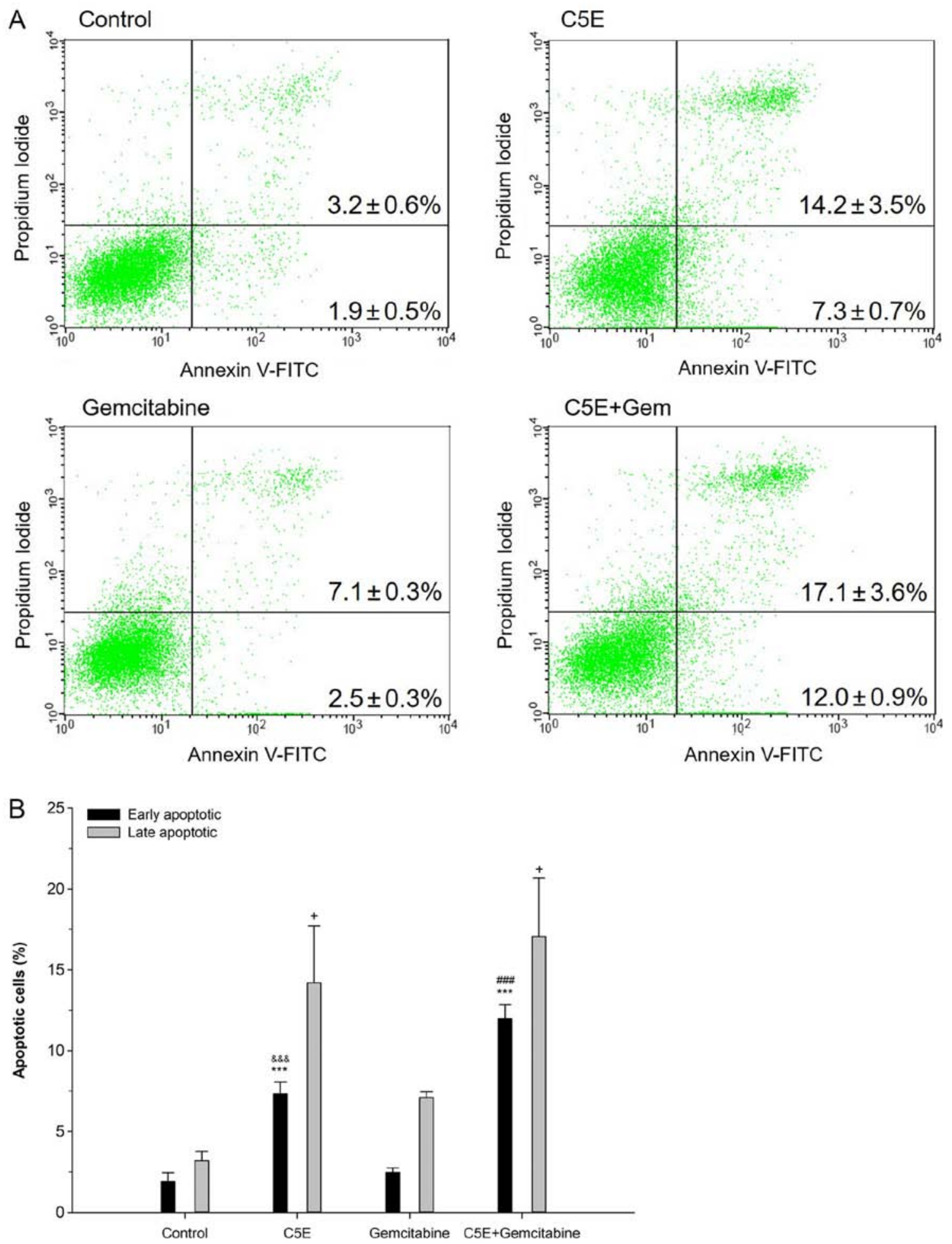

Figure 2. Early and late apoptotic rates of PANC-1 cells using Annexin V and PI double staining. (A) PANC-1 cells treated with C5E, gemcitabine or the combination were stained with FITC-conjugated Annexin V in a buffer containing PI and analyzed by flow cytometry. (B) Percentage of early apoptotic and late apoptotic cells in each treatment group from part (A). ${ }^{+} \mathrm{P}<0.05$ vs. late apoptotic cell death in the control group; ${ }^{* * *} \mathrm{P}<0.001$ vs. control early apoptotic; ${ }^{\& \& \&} \mathrm{P}<0.001$ vs. gemcitabine early apoptotic; ${ }^{\# \#} \mathrm{P}<0.001$ vs. C5E early apoptotic; ${ }^{+} \mathrm{P}<0.05$ vs. control late apoptotic. $\mathrm{PI}$, propidium iodide.

C5E and gemcitabine decreased to $15 \mu \mathrm{g} / \mathrm{ml}$ for C5E and $5 \mathrm{nM}$ for gemcitabine (Fig. S1C).

Analysis of cell cycle progression and apoptotic cell death. To determine the distribution of the cell cycle in cells following $\mathrm{C} 5 \mathrm{E}$ and gemcitabine treatment, cells were treated with $\mathrm{C} 5 \mathrm{E}$ and/or gemcitabine at their $\mathrm{IC}_{50}$ values. The treatment of PANC-1 cells with $30 \mu \mathrm{g} / \mathrm{ml} \mathrm{C5E}$ for $72 \mathrm{~h}$ significantly increased the percentage of cells in the $\mathrm{S}$ phase $(65.8 \pm 0.8 \%)$ compared with the control group $(40.2 \pm 0.8 \%)$, while concomitantly significantly reducing the percentage of cells in the $G_{0} / G_{1}$ and $G_{2} / M$ phases (Fig. 1A and $B$ ). The relative percentage increase in $\mathrm{S}$ indicated that the cell cycle progress was blocked by treatment $(26,27)$. In addition, the increase in 
A

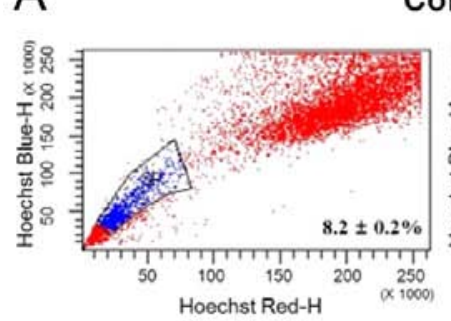

Control

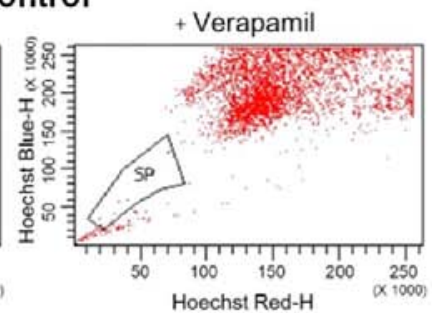

Gemcitabine
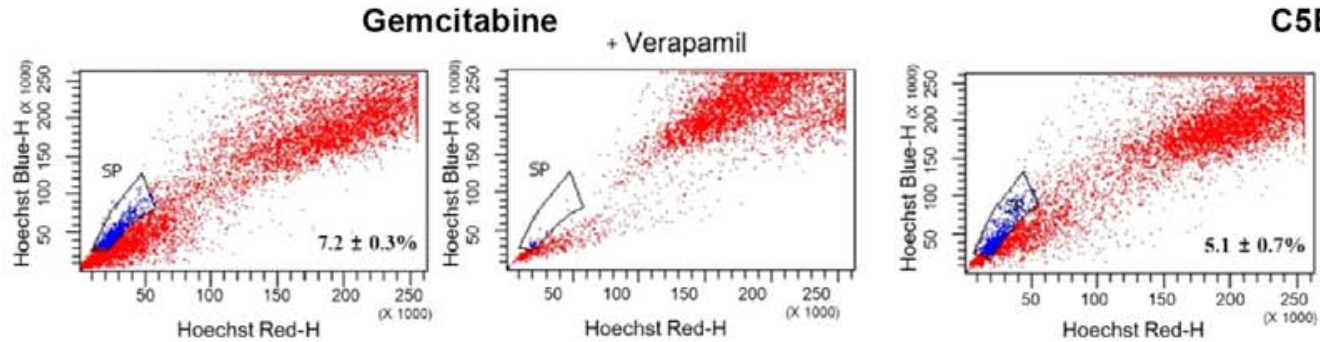

C5E + Gem

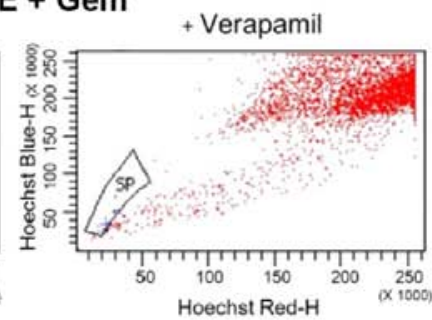

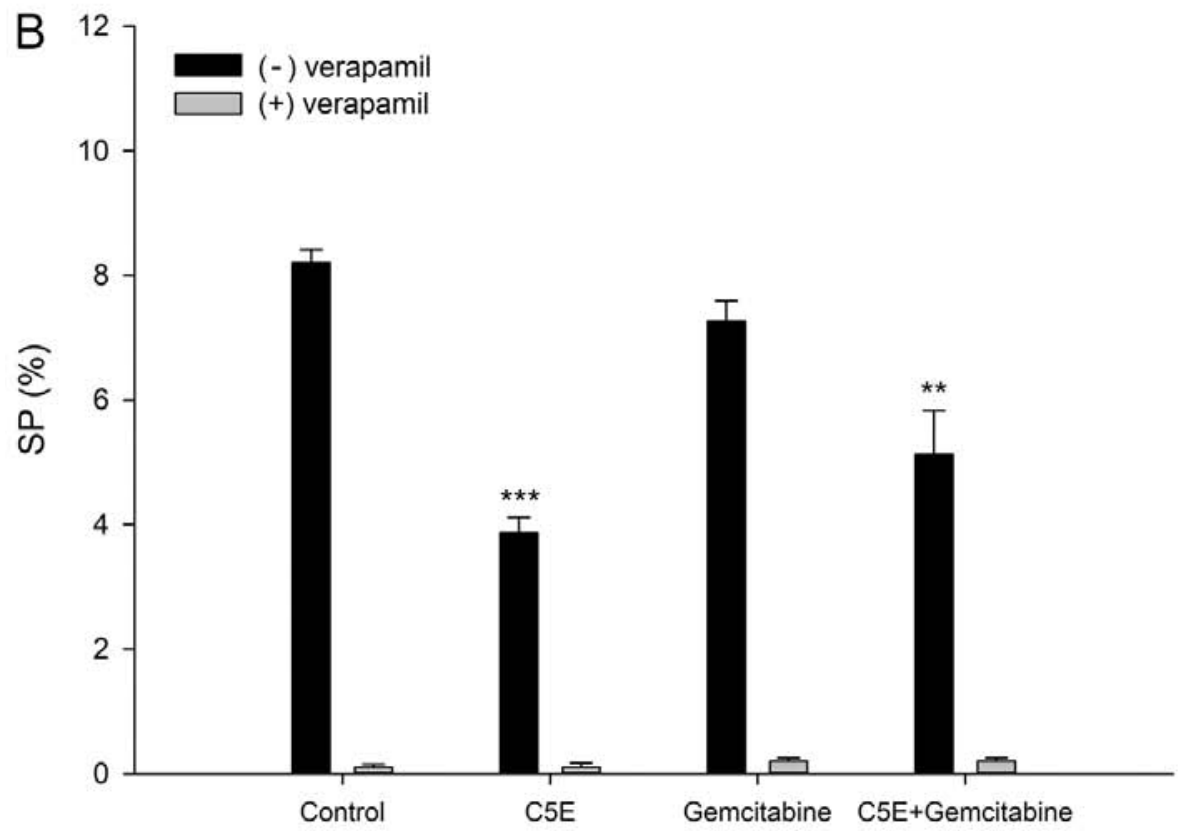

Figure 3. SP analysis following the treatment with C5E and/or gemcitabine. PANC-1 cells were treated with C5E and/or gemcitabine for $72 \mathrm{~h}$. (A) Proportion of SP and non-SP cells was analyzed in the presence of Hoechst 33342 or Hoechst 33342 plus verapamil (an inhibitor of multidrug resistance protein) using a FACSAria flow cytometer. (B) Quantification of the SP in each treatment group form part (A). ${ }^{* *} \mathrm{P}<0.01,{ }^{* * * *} \mathrm{P}<0.001 \mathrm{vs}$. control (-) verapamil. SP, side population.

the percentage of $\mathrm{S}$ phase cells following the treatment with gemcitabine $(49.2 \pm 2.5 \%)$ was significantly lower compared with the C5E treatment. Notably, the percentage of S phase cells following the co-treatment $(67.8 \pm 1.2 \%)$ was significantly increased compared with the treatment with gemcitabine-alone $(49.2 \pm 2.5 \%)$. These findings suggested that the co-treatment may have a synergistic effect on cell cycle arrest compared with the treatment with $\mathrm{C} 5 \mathrm{E}$ or gemcitabine alone. In addition, the inhibition of cell viability following the treatment with $\mathrm{C} 5 \mathrm{E}$ and/or gemcitabine may be related to $\mathrm{S}$ phase cell cycle arrest.

To analyze the effect of C5E on apoptosis, PANC-1 cells were treated with $\mathrm{C} 5 \mathrm{E}$ and/or gemcitabine for $72 \mathrm{~h}$, and the number of apoptotic cells was analyzed using Annexin V/PI double staining. The levels of early apoptosis in PANC-1 cells following C5E treatment were significantly increased $(7.3 \pm 0.7 \%)$ compared with the control group $(1.9 \pm 0.5 \%)$ (Fig. 2A and B). In addition, the levels of early apoptosis following $\mathrm{C} 5 \mathrm{E}$ treatment $(7.3 \pm 0.7 \%)$ were more than double that of the gemcitabine-induced levels of early apoptosis $(2.5 \pm 0.3 \%)$. Moreover, the levels of early apoptosis following the co-treatment were increased $(12.0 \pm 0.9 \%)$ by $10.1 \%$ compared with the control and by $4.7 \%$ compared with the C5E treatment alone (Fig. 2A and B). Late apoptosis was also assessed following the treatment with $\mathrm{C} 5 \mathrm{E}$ and/or gemcitabine. The levels of late apoptosis following the co-treatment were $17.1 \pm 1.6 \%$, which were increased compared with C5E treatment alone $(14.2 \pm 3.5 \%)$ and the control treatment $(3.2 \pm 0.6 \%)$. The overall trend was very similar to that observed for early apoptosis. Thus, these results suggested that the co-treatment 
A

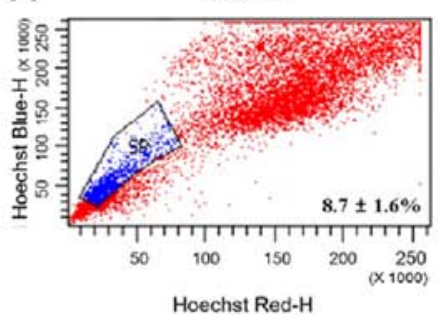

$\mathrm{IC} 25$

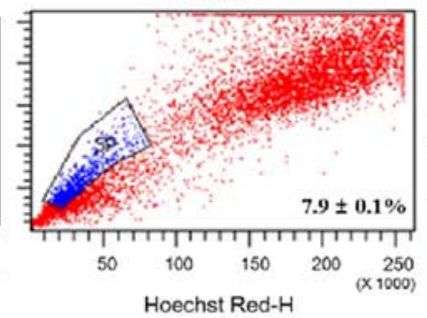

IC50

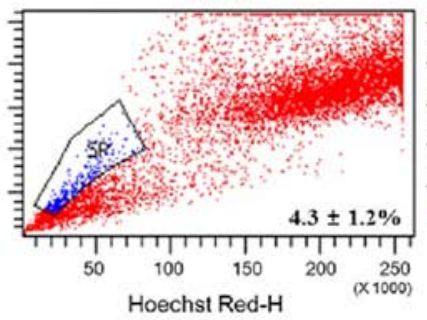

IC75

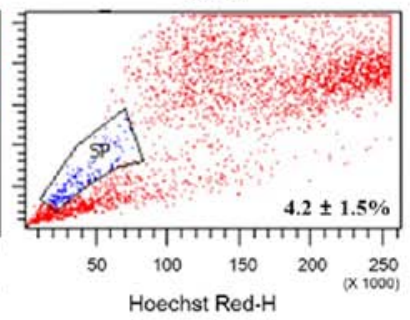

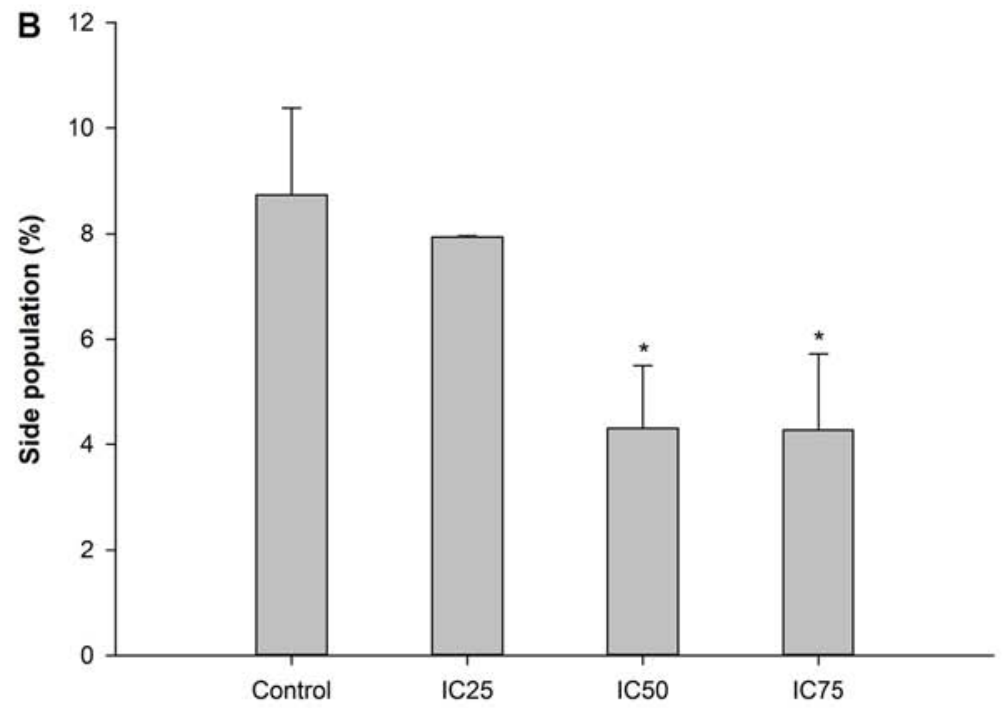

Figure 4. SP analysis following the treatment with different concentrations of C5E. PANC1 cells were treated with C5E at the $\mathrm{IC}_{25}, \mathrm{IC}_{50}$ and $\mathrm{IC}_{75}$ doses for $72 \mathrm{~h}$. (A) Proportion of SP and non-SP cells was analyzed in the presence of Hoechst 33342 or Hoechst 33342 plus verapamil on a FACSAria flow cytometer. (B) Quantification of the SP in each treatment group from part (A). ${ }^{*} \mathrm{P}<0.05$ vs. control. SP, side population.

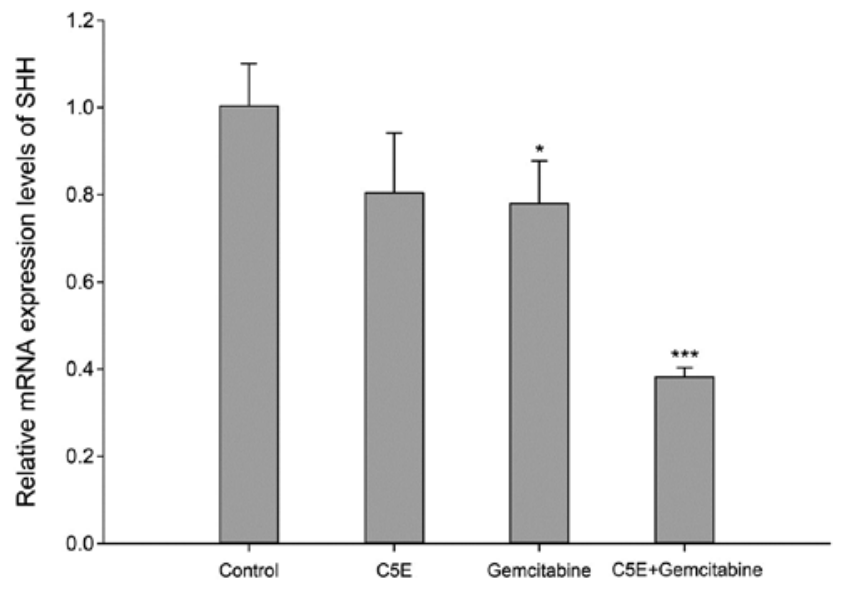

Figure 5. Expression levels of SHH in PANC-1 cells in the presence of C5E, gemcitabine or the combination treatment. mRNA expression levels of SHH were determined using reverse transcription-quantitative PCR. The housekeeping gene GAPDH was used as the internal control for normalization. The mean values of the fold change in mRNA expression levels for the SHH gene in each treatment group relative to the control are shown. Data are expressed as the mean $\pm \mathrm{SD}$ of $\geq 3$ independent experiments. ${ }^{*} \mathrm{P}<0.05$, ${ }^{* * * *} \mathrm{P}<0.001$ vs. control. SHH, sonic hedgehog.

may have a synergistic effect on apoptosis, as well as cell cycle progression.

Analysis of the SP. Subsequently, the proportion of SP cells following the treatment with $\mathrm{C} 5 \mathrm{E}$, gemcitabine or C5E plus gemcitabine was analyzed by Hoechst 33342 staining. As expected, verapamil, which is an inhibitor of ABC transporter, inhibited generation of SP cells. Flow cytometry analysis showed $8.2 \pm 0.2 \% \mathrm{SP}$ cells in the control group without verapamil treatment (Fig. 3A and B). A decrease in the percentage of SP cells in the PANC-1 cell culture was induced by $\mathrm{C} 5 \mathrm{E}$ and/or gemcitabine in the absence of verapamil treatment. The percentage of SP cells significantly decreased to $3.9 \pm 0.3 \%$ following treatment with C5E-alone and $7.2 \pm 0.3 \%$ following treatment with gemcitabine-alone compared with the control group. Notably, the percentage of SP cells was also significantly decreased to $5.1 \pm 0.7 \%$ following the co-treatment with $\mathrm{C} 5 \mathrm{E}$ and gemcitabine compared with the control group (Fig. 3). The percentage of SP cells with verapamil treatment were $<0.2 \%$ (Fig. 3B). Thus, the percentage of SP cells following the co-treatment decreased by less than C5E treatment alone. These results suggested that C5E may have a higher influence than gemcitabine on the reduction of the SP cell population. Subsequently, the changes in the percentage of SP cells at varying concentrations of $\mathrm{C} 5 \mathrm{E}$ were investigated. The percentage of SP cells was $7.9 \pm 0.1,4.3 \pm 1.2$ and $4.2 \pm 1.5 \%$, respectively, at the $\operatorname{IC}_{25}(10 \mu \mathrm{g} / \mathrm{ml}), \mathrm{IC}_{50}(30 \mu \mathrm{g} / \mathrm{ml})$ and the $\mathrm{IC}_{75}(50 \mu \mathrm{g} / \mathrm{ml})$ doses, indicating that the proportion of SP cells decreased with increasing concentration of C5E (Fig. 4A and B). Thus, the percentage of SP cells was significantly decreased at $\mathrm{IC}_{50}$ and $\mathrm{IC}_{75}$ compared with the control. However, the difference in the percentages was much smaller 
between the $\mathrm{IC}_{50}$ and $\mathrm{IC}_{75}$ doses compared with between the $\mathrm{IC}_{50}$ and $\mathrm{IC}_{25}$ doses.

Sonic hedgehog (SHH) expression levels following C5E and/or gemcitabine treatment. SHH is a stem cell-associated gene, which has been implicated in the development of pancreatic cancer cells (28). The expression levels of SHH were analyzed following the treatment with $\mathrm{C} 5 \mathrm{E}$ and/or gemcitabine using RT-qPCR. The results revealed that $\mathrm{SHH}$ expression levels were downregulated by $\sim 20 \%$ following the treatment with C5E or gemcitabine alone compared with the control group (Fig. 5). However, the expression levels of SHH were significantly downregulated by $\sim 60 \%$ following the co-treatment with $\mathrm{C} 5 \mathrm{E}$ and gemcitabine compared with the control group (Fig. 5). Thus, the downregulation in SHH mRNA expression levels was more significant upon the co-treatment with C5E and gemcitabine compared with the treatment with each individual compound. These data indicated that $\mathrm{C} 5 \mathrm{E}$ and gemcitabine may exert a synergistic effect with respect to the inhibition of SHH mRNA expression levels.

\section{Discussion}

The present study reported that C5E herbal mixture extracts, which consists of ten traditional herbs, may be useful in combination with chemotherapeutic drugs to increase the efficacy of chemotherapy for pancreatic cancer cells, by decreasing the necessary treatment volume of gemcitabine. Our previous study demonstrated that herbal mixture extracts reduced the survival of CSCs, which are associated with relapse and metastases (7). In the present study, an ethanol extract of herbal mixture $\mathrm{C} 5 \mathrm{E}$ containing Panax ginseng, Inonotus obliquus and 8 other herbs was used. In a previous study, gas chromatography-mass spectrometry analysis of the herbal extract C5E identified that some of the components, including angelicin (24.54\%) and coumarin $(2.65 \%)$, serve active anticancer roles (16). Thus, several components of $\mathrm{C} 5 \mathrm{E}$ have already been shown to be involved in the suppression of cancer cells. For example, a previous study identified that the treatment with angelicin, the most dominant component of $\mathrm{C} 5 \mathrm{E}$, induced apoptosis in neuroblastoma cells (29). Coumarin, a minor component of $\mathrm{C} 5 \mathrm{E}$, has also received increasing attention because of its antiangiogenic activity (30). Another previous study revealed that the herbal extract $\mathrm{C} 5 \mathrm{E}$ induced apoptosis in human breast cancer cells, including MCF7 cells (16). The present study demonstrated the potential extended application of $\mathrm{C} 5 \mathrm{E}$ to other types of cancer cell, such as PANC-1 cells.

Firstly, the conditions for the treatment of PANC-1 cells with $\mathrm{C} 5 \mathrm{E}$ in the absence or presence of gemcitabine were optimized. C5E treatment was observed to inhibit the viability of PANC-1 cells through the induction of S phase cell cycle arrest. These findings indicated that C5E may exert its effect through a mechanism similar to that of gemcitabine. However, the extent of $\mathrm{S}$ phase cell cycle arrest was increased following C5E treatment compared with gemcitabine treatment. Several anticancer drugs, including gemcitabine and clofarabine, have been reported to exert their effects through cell cycle arrest at the $S$ phase $(26,27)$. It has been established that gemcitabine exerts its anticancer effect by delaying the DNA replication forks during the $\mathrm{S}$ phase of the cell cycle (31). In the present study, C5E was discovered to induce cell death through early apoptosis, as has been observed with gemcitabine in previous studies (28-30) (Fig. 2). The majority of chemotherapy drugs induce apoptosis $(31,32)$. The results revealed that the co-treatment with C5E and gemcitabine was markedly more effective compared with the individual treatments alone at inducing $\mathrm{S}$ phase cell cycle arrest and early apoptosis. These findings indicated that $\mathrm{C} 5 \mathrm{E}$ may be used alone or as an adjuvant drug for chemotherapy with the standard drug gemcitabine for the treatment of pancreatic cancer.

Subsequently, the present study investigated the general effect of C5E on the human pancreatic carcinoma cell line PANC-1 and its subpopulation of CSCs. Changes in SP cell proportions were used to evaluate the effects on CSCs (33). In the initial stages of the study, several pancreatic cancer cell lines (Capan-1 or 2, MIA-PaCa-2 and PANC-1) were examined to identify cell lines that have a substantial percentage of SP cells; however, only PANC-1 cells had sufficient SP cells to study the effect on CSCs (data not shown). The average percentage of SP cells present in among the whole population of PANC-1 cells was revealed to be $5-10 \%$, which is consistent with the findings of previous reports $(34,35)$. Thus, PANC-1 cells were selected for all following experiments. The current results discovered that the percentage of SP cells was markedly decreased following the treatment with C5E alone. More importantly, the extent of the decrease was higher following C5E treatment compared with gemcitabine treatment. This suggested the possibility of using C5E as a complementary drug to target the CSCs of the PANC-1 cell population, thus obtaining a synergistic effect alongside gemcitabine drugs for the treatment of pancreatic cancer. However, additional research with several other pancreatic cell lines is required to verify the effects of $\mathrm{C} 5 \mathrm{E}$. The present study further investigated the molecular mechanism by which C5E may exert its anticancer effects, in particular, its effects on the expression levels of SHH. The mRNA expression levels of SHH serve as a marker of CSCs, and numerous studies have reported that $\mathrm{SHH}$ regulates the proliferation of stem cells and blocks $\mathrm{SHH}$ via the Hedgehog (Hh) pathway; this may be a novel therapeutic strategy (36-38). The SHH mRNA expression levels were discovered to be downregulated to a similar extent following the treatment with either C5E or gemcitabine; however, the co-treatment with $\mathrm{C} 5 \mathrm{E}$ and gemcitabine downregulated the expression levels of $\mathrm{SHH}$ to a greater extent compared with the treatment with $\mathrm{C} 5 \mathrm{E}$ or gemcitabine alone. C5E in combination with gemcitabine may serve a role as a Hh pathway antagonist (38). Nonetheless, despite the current study demonstrating that C5E may be useful for the treatment of pancreatic cancer, in vivo animal experiments should be performed to ensure the safety and efficacy of the C5E herbal extract for the treatment of pancreatic cancer.

In conclusion, the findings of the present study suggested that the herbal mixture extract C5E may be used as a complementary drug with gemcitabine against pancreatic cancer cells and CSCs. Both combinatorial therapies and monotherapies should be considered for the development of effective cancer therapies. C5E with gemcitabine may serve as a potential candidate for complementary use in the treatment of pancreatic cancer as it was revealed to exert synergistic effects in pancreatic cancer cells. 


\section{Acknowledgements}

Not applicable.

\section{Funding}

The present study was supported by a grant from the Korean Health Technology R\&D Project, Ministry of Health \& Welfare, Republic of Korea (grant no. B110053).

\section{Availability of data and materials}

The datasets used and/or analyzed during the present study are available from the corresponding author on reasonable request.

\section{Authors' contributions}

PJP conceptualized the research and drafted the manuscript. JHS and DGL analyzed the data. SHJ, TYH, SHP and NC interpreted the data. NC supervised the research and revised the manuscript All authors read and approved the final manuscript.

\section{Ethics approval and consent to participate}

Not applicable.

\section{Patient consent for publication}

Not applicable.

\section{Competing interests}

The authors declare that they have no competing interests.

\section{References}

1. Barnes AF, Yeo TP, Leiby B, Kay A and Winter JM: Pancreatic cancer-associated depression: A case report and review of the literature. Pancreas 47: 1065-1077, 2018.

2. Yachida S, Jones S, Bozic I, Antal T, Leary R, Fu B, Kamiyama M, Hruban RH, Eshleman JR, Nowak MA, et al: Distant metastasis occurs late during the genetic evolution of pancreatic cancer. Nature 467: 1114-1117, 2010.

3. Skelton WP IV, Parekh H, Starr JS, Trevino J, Cioffi J, Hughes S and George TJ Jr: Clinical factors as a component of the personalized treatment approach to advanced pancreatic cancer: A systematic literature review. J Gastrointest Canc 49: 1-8, 2018.

4. Yang L, Shi P, Zhao G, Xu J, Peng W, Zhang J, Zhang G, Wang X, Dong Z, Chen F and Cui H: Targeting cancer stem cell pathways for cancer therapy. Signal Transduct Target Ther 5: 8, 2020.

5. Valle S, Martin-Hijano L, Alcalá S, Alonso-Nocelo M and Sainz B Jr: The ever-evolving concept of the cancer stem cell in pancreatic cancer. Cancers (Basel) 10: 33, 2018.

6. Codony-Servat J, Codony-Servat C, Cardona AF, GiménezCapitán A, Drozdowskyj A, Berenguer J, Bracht JWP, Ito M, Karachaliou N and Rosell R: Cancer stem cell biomarkers in EGFR-mutation-positive non-small-cell lung cancer. Clin Lung Cancer 20: 167-177, 2019.

7. Batlle $\mathrm{E}$ and Clevers $\mathrm{H}$ : Cancer stem cells revisited. Nat Med 23: 1124-1134, 2017.

8. Li F, Tiede B, Massagué J and Kang YB: Beyond tumorigenesis: Cancer stem cells in metastasis. Cell Res 17: 3-14, 2007.

9. Taylor WF and Jabbarzadeh E: The use of natural products to target cancer stem cells. Am J Cancer Res 7: 1588-1605, 2017.
10. Patrawala L, Calhoun T, Schneider-Broussard R, Zhou J, Claypool K and Tang DG: Side population is enriched in tumorigenic, stem-like cancer cells, whereas ABCG2+ and ABCG2-cancer cells are similarly tumorigenic. Cancer Res 65: 6207-6219, 2005

11. Goodell MA, Brose K, Paradis G, Conner AS and Mulligan RC: Isolation and functional properties of murine hematopoietic stem cells that are replicating in vivo. J Exp Med 183: 1797-1806, 1996.

12. Sung JH, Kim JB, Park SH, Park SY, Lee JK, Lee HS and Chung N: Berberine decreases cell growth but increases the side population fraction of h460 lung cancer cells. J Korean Soc Appl Biol Chem 55: 491-495, 2012.

13. Shaito A, Thuan DTB, Phu HT, Nguyen THD, Hasan H, Halabi S, Abdelhady S, Nasrallah GK, Eid AH and Pintus G: Herbal medicine for cardiovascular diseases: Efficacy, mechanisms, and safety. Front Pharmacol 11: 422, 2020.

14. Izzo AA and Capasso F: Herbal medicines to treat Alzheimer's disease. Trends Pharmacol Sci 28: 47-48, 2007.

15. Yun Y, Kim K, Choi I and Ko SG: Topical herbal application in the management of atopic dermatitis: A review of animal studies. Mediat Inflamm 2014: 752104, 2014.

16. Lee S, Han S, Park JS, Jeong AL, Jung SH, Choi KD, Han TY, Han IY and Yang Y: Herb mixture C5E aggravates doxorubicin-induced apoptosis of human breast cancer cell lines. J Korean Soc Appl Biol Chem 56: 567-573, 2013.

17. Aung TN, Qu ZP, Kortschak RD and Adelson DL: Understanding the effectiveness of natural compound mixtures in cancer through their molecular mode of action. Int J Mol Sci 18: 656, 2017.

18. Lee DG, Go EB, Lee M, Pak PJ, Kim JS and Chung N: Gold nanoparticles conjugated with resveratrol induce cell cycle arrest in MCF-7 cell lines. Appl Biol Chem 62: 33, 2019.

19. Jeon HJ, Kim K, Kim YD and Lee SE: Naturally occurring piper plant amides potential in agricultural and pharmaceutical industries: Perspectives of piperine and piperlongumine. Appl Biol Chem 62: 63, 2019.

20. Park JY, Choi P, Kim HK, Kang KS and Ham J: Increase in apoptotic effect of Panax ginseng by microwave processing in human prostate cancer cells: in vitro and in vivo studies. J Ginseng Res 40: 62-67, 2016.

21. Yoo HS, Kim JM, Jo E, Cho CK, Lee SY, Kang HS, Lee MG, Yang PY and Jang IS: Modified Panax ginseng extract regulates autophagy by AMPK signaling in A549 human lung cancer cells. Oncol Rep 37: 3287-3296, 2017.

22. Kim YO, Park HW, Kim JH, Lee JY, Moon SH and Shin CS: Anti-cancer effect and structural characterization of endo-polysaccharide from cultivated mycelia of Inonotus obliquus. Life Sci 79: 72-80, 2006

23. Burmasova MA, Utebaeva AA, Sysoeva EV and Sysoeva MA: Melanins of Inonotus obliquus: Bifidogenic and antioxidant properties. Biomolecules 9: 248, 2019.

24. Voigt M, Bartels I, Nickisch-Hartfiel A and Jaeger M: Determination of minimum inhibitory concentration and half maximal inhibitory concentration of antibiotics and their degradation products to assess the eco-toxicological potential. Toxicol Environ Chem 101: 315-338, 2019.

25. Livak KJ and Schmittgen TD: Analysis of relative gene expression data using real-time quantitative PCR and the 2(-Delta Delta C(T)) method. Methods 25: 402-408, 2001.

26. Guo Y, Xu X, Qi W, Xie C, Wang G, Zhang A and Ge Y: Synergistic antitumor interactions between gemcitabine and clofarabine in human pancreatic cancer cell lines. Mol Med Rep 5: 734-738, 2012.

27. Miao X, Koch G, Ait-Oudhia S, Straubinger RM and Jusko WJ: Pharmacodynamic modeling of cell cycle effects for gemcitabine and trabectedin combinations in pancreatic cancer cells. Front Pharmacol 7: 421, 2016.

28. Reya T, Morrison SJ, Clarke MF and Weissman IL: Stem cells, cancer, and cancer stem cells. Nature 414: 105-111, 2001.

29. Rahman MA, Kim NH, Yang H and Huh SO: Angelicin induces apoptosis through intrinsic caspase-dependent pathway in human SH-SY5Y neuroblastoma cells. Mol Cell Biochem 369: 95-104, 2012.

30. Majnooni MB, Fakhri S, Smeriglio A, Trombetta D, Croley CR, Bhattacharyya P, Sobarzo-Sanchez E, Farzaei MH and Bishayee A: Antiangiogenic effects of coumarins against cancer: From chemistry to medicine. Molecules 24: 4278, 2019. 
31. Vogus DR, Evans MA, Pusuluri A, Barajas A, Zhang M, Krishnan V, Nowak M, Menegatti S, Helgeson ME, Squires TM and Mitragotri S: A hyaluronic acid conjugate engineered to synergistically and sequentially deliver gemcitabine and doxorubicin to treat triple negative breast cancer. J Control Release 267: 191-202, 2017

32. Utaipan T, Boonyanuphong P, Chuprajob T, Suksamrarn A and Chunglok W: A trienone analog of curcumin, 1,7-bis(3-hydroxyphenyl)-1,4,6-heptatrien-3-one, possesses ROS- and caspase-mediated apoptosis in human oral squamous cell carcinoma cells in vitro. Appl Biol Chem 63: 7, 2020.

33. Wu C and Alman BA: Side population cells in human cancers. Cancer Lett 268: 1-9, 2008

34. Bhagwandin VJ, Bishop JM, Wright WE and Shay JW: The metastatic potential and chemoresistance of human pancreatic cancer stem cells. PLoS One 11: e0148807, 2016.

35. Yao J, Cai HH, Wei JS, An Y, Ji ZL, Lu ZP, Wu JL, Chen P, Jiang KR, Dai CC, et al: Side population in the pancreatic cancer cell lines SW1990 and CFPAC-1 is enriched with cancer stem-like cells. Oncol Rep 23: 1375-1382, 2010.
36. Han L, Jiang J, Ma QY, Wu Z and Wang Z: The inhibition of heme oxygenase-1 enhances the chemosensitivity and suppresses the proliferation of pancreatic cancer cells through the $\mathrm{SHH}$ signaling pathway. Int J Oncol 52: 2101-2109, 2018.

37. Douard R, Moutereau S, Pernet P, Chimingqi M, Allory Y, Manivet P, Conti M, Vaubourdolle M, Cugnenc PH and Loric S: Sonic hedgehog-dependent proliferation in a series of patients with colorectal cancer. Surgery 139: 665-670, 2006.

38. De Sauvage FJ: Targeting the hedgehog pathway in cancer. Ann Oncol 20: 18, 2009.

cc) (i) (3) This work is licensed under a Creative Commons Attribution-NonCommercial-NoDerivatives 4.0 International (CC BY-NC-ND 4.0) License. 